\title{
Philippe Pinel, linguist: his work as translator and editor
}

\author{
By Dora B. Weiner
}

Of all the early writers in the field of psychiatry, Philippe Pinel (1745-1826) is by far the best known. His textbook, Traité médico-philosophique sur l'aliénation mentale ou la manie (1800) was the only such book repeatedly translated into foreign languages. Thus, the Hungarian physician Michael Wagner produced an excellent German version as early as $1801^{1}$, a Spanish translation, by Dr. Guarnerio y Allavena, appeared as early as $1804^{2}$, the English doctor D. Davis published an English edition in $1806^{3}$, and the Italian physician C. Vaghi followed suit in $1830^{4}$. The French innovator's thought thus reached the whole civilized world. The question raised in this short paper is whether the reverse was true: how open was Pinel to foreign influences?

In his knowledge or ignorance of foreign languages, Pinel was typical of his time and country. The thinkers of the Enlightenment were all good classicists, and the French appreciated contemporary English writers above all others. An excellent early education in a school run by the Pères de la doctrine chrétienne gave Pinel thorough Greek and Latin training. He retained an active familiarity with the classical writers on medical and psychologic topics all his life. In fact, about half of the substantial professional library of 234 books he left at his death was in Latin. These volumes included not only the classic authors, but modern writers who used Latin, for example the Swede Linnaeus, the German Friedrich Hoffmann, the Austrian Maximilian Stoll, the Swiss von Haller, the Dutchman Boerhaave, and the Italian Morgagni. One of Pinel's earliest publishing ventures was a new Latin edition of Giorgio Baglivi's collected works ${ }^{5}$. Pinel added a modest eight-page Latin preface; his notes are few and, when critical, polite, such as the doubts Pinel expresses that the bite of the tarantula can be cured by music ${ }^{6}$.

Yet, while they still considered Latin as an essential tool, Pinel's contemporaries most frequently used their vernacular languages. The question whether their works were translated, or whether foreigners read the writer's idiom, thus assumes importance. Of all of modern languages, Pinel knew English best. He used it to help support himself, in those fifteen years, 
from 1778 to 1793, when he lived in Paris, lacking an appropriate job. Indeed, before the Revolution, his Toulouse medical degree barred him from earning a livelihood in Paris as a physician. He made enough money for his modest needs as a bachelor by tutoring, newspaper work, and translations. This is when he undertook an English version of William Cullen's Institutes of Practical Medicine, for the Paris publisher Duplain ${ }^{7}$.

In the translator's Preface, Pinel lauds qualities in Cullen that he himself became famous for. This Preface has never been translated, and Pinel's remarks about Cullen might thus be of some interest:

"From the practice of nosology," wrote Pinel, "M. Cullen has learned attention to order and method which are his special characteristics. His principles are conceived and developed with precision: they contain faithful and exact case histories, tracing the coexistence or succession of symptoms. He presents the remedies and limitations of our Art with disingenuous frankness, and bases appropriate therapy on established facts, usually derived from the Author's own experience. His sensible method is remarkable for the constant attention to regimen, to exercise and rest, and to the other helpful suggestions derived from Hygiene". 8

"... psychologic and physical remedies and therapy are always prescribed together with the circumstances that should dictate their choice" 19

Pinel even adds some remarks on Cullen's style, foreshadowing his own attention to the clear, concise, and simple expression that characterize his prose. Had he felt free to edit Cullen's style, he would

"have tried to make it more concise and to rid it of an overabundance of adverbs, used too freely, and of uniform and repetitive phrases, particularly striking for those who know English literature".

But, concludes Pinel, "I wanted to enable the public to judge this author independently ... Therefore, I have added neither notes nor comments." 10

Unfortunately for Pinel's pride, for his publisher, and especially for his pocketbook, a rival translation of Cullen's book, by E.F.M.Bosquillon (1744-1816), appeared the same year. For reasons that remain obscure, Bosquillon's translation reaped far greater success than Pinel's. But their rivalry does not appear to have soured feelings between the two translators. Indeed, four years later, we find them collaborating on a very ambitious undertaking. The editor Buisson decided to use the French educated public's keen interest in things English, particularly in the Royal Society of London, and publish Abstracts of the Society's Proceedings in French.

Buisson chose an experienced editor-in-chief, Jacques Gibelin (1744-1828), who had previously translated thirteen volumes of Joseph 
Priestley's work, and one volume each by Felice Fontana and Richard Kirwan. In undertaking to abstract over one hundred years' communications to the Royal Society, however, Gibelin overestimated his own efficiency. Fortunately for the enterprise, he began with his own specialties, botany, agriculture, horticulture, and rural economy. Being a careful scholar, he embarked upon an alphabetized description of all the plants presented to the Royal Society since the 1660s. This job took many months, and Gibelin soon realized that, if he wanted to see the project through to completion, he must coopt collaborators. The results appear on the following Table.

Abrégé des transactions de la Société royale de Londres

\begin{tabular}{lllr}
\hline vol. & Editor & Title & Year \\
\hline I. & Anon. [J.Gibelin] & $\begin{array}{l}\text { Abrégé des Transactions philosophiques de la } \\
\text { Société royale de Londres }\end{array}$ & {$[1789]$} \\
II. & J.Gibelin & $\begin{array}{l}\text { Botanique, agriculture, jardinage, } \\
\text { économie rurale }\end{array}$ & 1790 \\
III. & J.Gibelin & Physique expérimentale 2 vols. & 1790 \\
IV. & J.L.A. Reynier & Chimie & 1790 \\
V. & P.Pinel & Anatomie et physique animale & 1791 \\
VI. & P.Pinel & Médecine et chirurgie & 1790 \\
VII. & P.Pinel & Matière médicale et pharmacie & 1791 \\
VIII. & Wilmet and E. F. M. Bosquillon & 1791 \\
IX. & Bosquillon and Pinel & Part 2 & 1791 \\
X. & A.L. Millin de Grandmaison & Mélanges, Observations, Voyages & 1791 \\
XI. & & Antiquité, Beaux-Arts & 1790 \\
XII. & & & 1791 \\
\hline
\end{tabular}

In his Preface, Gibelin explains how arduous was the labor he undertook, largely because the Philosophical Transactions presented communications in chronologic order, and he aimed at a thematic organization.

"Imagine the effort and difficulties," he wrote, "involved in the choice, emendation, and arrangement of innumerable items that cover all the sciences, heaped helter-skelter into seventy-five in $-4{ }^{\circ}$ volumes that are, moreover, written in a foreign language". ${ }^{11}$ 
Pinel undertook the same process, for chemistry, anatomy, physiology, medicine, surgery, materia medica and pharmacy. This involved scanning one hundred years' work, contributed by the learned from all over Europe. At least, he did this for volumes 6 and 7, where he served as sole editor. (It is not possible to determine his exact part as co-editor of volumes 5 and 9 . In volume 5, the editors faced a peculiar problem: the nomenclature and quantitative basis of chemistry had recently undergone a revolution. Most of the articles in Transactions, based on the discarded phlogiston theory, had mere historic interest. The editors therefore emphasized the most recent contributions, and the applications of chemistry to industry.)

Of all twelve volumes in this series, volumes 6 and 7 are the only with lengthy editorial Notes. In these, Pinel justifies his selections, emphasizes French communications to the Royal Society (particularly those of an anatomist and surgeon called Bussière). At times, Pinel appears impatient at the anecdotal content of the Transactions. (The membership of the Royal Society was, after all, predominantly y mixture of wealthy and talented amateurs.)

The contents of volume 6 are arranged as follows:

Part I. General facts and research in anatomy

1. Anatomic facts related to the sexual organs and production of the foetus

2. Anatomic observations on the unnatural state of certain viscera

3. Anatomic peculiarities due to the altered position of certain viscera or the unnatural growth of certain body parts

Part II. Animal physiology

1. Human physiology

2. General animal physiology

In a Preface, Pinel tells us that he has emphasized selections on morbid anatomy, so that therapeutics can be discussed. This was the most useful approach. Whenever possible, he chose pieces of real scientific worth, such as a Letter from John Friend to Sir Hans Sloane on a hydrocephalus ${ }^{12}$, or a long essay by John Hunter on animal heat ${ }^{13}$. He turned an article on electricity into an opportunity to write a lengthy and learned disquisition on its therapeutic uses ${ }^{14}$. But, try as he might, he found the Transactions' attention to serious anatomy and physiology sporadic. The emphasis was on scientific news, not on medicine and thoughtful analysis. So, eventually, he gave up, and included short pieces on Siamese twins in Hungary, a hermaphrodite in London, and a pregnant mother, hit by a cow's udder, 
whose child was born with an udder-shaped excrescence attached to her head $^{15}$, or a woman with horns on her thighs ${ }^{16}$.

To salvage his dignity, and whenever appropriate, Pinel added serious Notes with observations by great scientists, physicians, or surgeons, such as Linnaeus, the comte de Buffon, Jacques Tenon, Pierre Joseph Desault, or Antoine Portal ${ }^{17}$. An article on blood-transfusion, for example, elicited the following, typical, comment from Pinel-quite erroneous, in the long run, of course:

"I thought I should mention transfusion, even though it was soon completely proscribed in France and England. This strange method, whose promoters expected so many advantages, suffered the fate of all methods based on nothing but empty guesswork. Any precise and rigorous mind, enlightened by experiments, will soon discard it. In France, several persons died in these trials, and when the [Paris] Parlement was informed, it interposed its authority. It issued a decree that prohibited similar operations, under severe penalties.

The infusions of medicinal liquids into the veins was no more successful. And yet it is interesting to know these facts ..." 18

In the Preface to volume 6, Pinel concludes, resigned, and in self-defense:

"One cannot hide the fact that the Royal Society of London, particularly at the beginning, has not always been very rigorous in the choice of the Memoirs to be included in the Transactions. I have therefore sought, in my translation, to avoid the same reproach, and not to adopt haphazardly everything found in the English original". ${ }^{19}$

To compose volume 7 was undoubtedly a more satisfying experience for Pinel. The contents are as follows:
Part I. Medicine
1. Demographic Calculations
2. Organic Diseases
3. Fevers and other Illnesses
Part II. Surgery
1. Lithotomy
2. Wounds
3. On some Surgical Procedures.

Pinel judged the articles in this volume important

\footnotetext{
"because the authors have limited themselves to factual accounts and to the consequences to be derived for practice, without losing themselves in vague theories and views dictated by [medical] systems". ${ }^{20}$
}

He grouped articles on mortality and actuarial tables, 
"a branch of medicine hardly known in France and that deserves special attention because of its relationship to politics and to the theory of annuities". ${ }^{21}$

He chose studies on inoculation, on the plague of Constantinople in 1758 and in Marseilles in 1720:

"It is particularly interesting to collect comparative data, since they teach the distinguishing characteristics of plague and malignant fevers". ${ }^{22}$

Pinel even included a successful medical consultation of his own, in a Note on kidney stones: he counselled a patient suffering from these to work at a stand-up desk and drink much tea. These prescriptions "produced the hoped-for effect and the pain in back and bladder disappeared." 23

Of special interest are Pinel's remarks on camphor used to control mania, "one of the most interesting topics in medicine." 24 He therefore included a paper on this subject by G. Oliver, physician to the Prince of Wales ${ }^{25}$. He also added a discussion of a mute person who recovered speech after a frightening dream, the study of three brains of epileptics, an example of periodic paralysis, and the case of a man who turned blind, only after sundown ${ }^{26}$. Knowing Pinel's subsequent career, these passages arouse a reader's curiosity.

In volume 9, on materia medica, Pinel decided that discussions of air, the atmosphere, and the "epidemic constitution" were appropriate. Therefore, he included "Experiments Upon Air, and the Effects of Different Effluvia Upon it." In his comments, he discussed the role of plants and how sunlight helps them produce oxygen (a recent discovery), and how fresh air provided a powerful remedy. He refers to the latest research by Alessandro Volta and Jan Ingenhousz ${ }^{27}$. In other words, Pinel took considerable liberties, in his role as editor, broadening his function as translator into that of a cultural ambassador for foreign scientific ideas in France.

But the appearance of the Abrégés in 1790-1791 was ill timed. These volumes could not find much of a readership when a cataclysm was engulfing France.

For the subsequent twenty-five years, France was at war with England, and direct communication was difficult. Indirectly, however, French scholars and physicians remained in touch with the British professional scene. This achievement is due to a series published at Geneva, the Bibliothèque britannique $^{28}$. Pinel's library, at the time of his death, contained forty-two volumes of this series. 
It was through this journal that the French medical world first learned of Edward Jenner's epoch-making discovery in 1798, for example. That same year appeared a book by a Scottish physician, Alexander Crichton (1763-1856), that was to be of prime importance for Pinel, An Inquiry into the Nature and Origin of Mental Derangement, Comprehending a Concise System of Physiology and Pathology of the Human Mind, and History of the Passions and their Effects ${ }^{29}$. Pinel devoted nineteen pages, one-third of the Introduction of the Treatise on Insanity, to Crichton. He saw in his Lockean, empirical, associationist approach to mental illness a theory, an attitude tow ard the patient, and a conception of therapy that he shared. Here, Pinel argued, was the modern orientation that the psychologically-minded physician should follow.

Pinel did not translate Crichton's book. As a matter of fact, from 1793 on, that is, once he obtained a professional appointment commensurate with his knowledge and aptitudes, Pinel's days as translator were over.

But the linguist in Pinel continued to play an important part - negative as well as positive. The Introduction to Pinel's Treatise is a reliable guide to his attitude toward foreign writings.

In this Introduction, Pinel fondly lists a number of ancient authors, still valid for the study of mental illness: Hippocrates, Aretaeus of Cappadocia, Celsus, Caelius Aurelianus, and Galen. He also mentions some of the numerous modern authors whose works he owned in Latin, namely Jan Baptista van Helmont, Georg Ernst Stahl, and Hermann Boerhaave, as well as three serial publications: the Acta Hafniensia, Albrecht von Haller's Disputationes ad morborum historiam, and Gerard L.B.van Swieten's Constitutiones epidemicae, edited by Maximilian Stoll.

Pinel's list of British authors important to early psychiatry is lengthy, yet he did not own any of them, except for Adam Smith's Theory of Moral Sentiments, but in the French translation by Condorcet's widow:

Pinel's «Traité médico-philosophique»

British sources mentioned in the Introduction:

Thomas Arnold, Observations on the Nature, Kinds, Causes, and Prevention of Insanity (Leicester: Robinson \& Cadell, 1782 and 1786)

William Battie, Treatise on Madness (London: Whiston \& White, 1758)

Sir Alexander Crichton, An Inquiry into the Nature and Origin of Mental Derangement, Comprehending a Concise System of Physiology and Pathology of the Human Mind and History of the Passions and Their Effects, 2 vols. (London: Cadell, Jr. \& Davies, 1798) 
John Ferriar, Medical Histories and Reflections (London: Cadell \& Davies, 1792)

Andrew Harper, A Treatise on the Real Cause and Cure of Insanity; in which the Nature and

Distinctions of this Disease are fully explained, and the Treatment established on new Principles (London: Stalker \& Walter, 1789)

William Pargeter, Observations on Maniacal Disorders (Reading: For the author, 1792)

William Perfect, Select Cases in the Different Species of Insanity, Lunacy, or Madness, with the

Modes of Practice as Adopted in the Treatment of Each (Rochester: Gillman, 1787)

Adam Smith, Theory of Moral Sentiments, 1759

As for Pinel's grasp of German, the uncomprehending negligence with which he presents German authors speaks for itself:

Pinel's «Traité médico-philosophique»

German books listed:

As they appear in Pinel's text*:

Faucett uber Mélancholie, Léipsick, 1785

Avenbrugger von der stillen, etc. 1783

$\begin{array}{lll}\text { Greding's } & \text { Vermischte, } \text { etc. } & 1781\end{array}$

Zimmermann von D.Erfahz. 1765

Weickard's Philosph.arzt Léipsick, 1775

p. 20, n. 1 . For correct citation, see endnote ${ }^{30}$

These entries indicate that Pinel did not understand what he was writing.

Not to take German scholarship seriously was a French attitude typical in 1800, and contemporary military and political events compounded the contempt. Pinel failed even to notice the greatest of his German counterparts, the physiologist Johann Christian Reil (1759-1813) whose book on psychiatry appeared in 1803. It was entitled Rhapsodieen über die Anwendung der psychischen Curmethode auf Geisteszerrüttungen ${ }^{31}$, and makes for extremely difficult reading. Reil had many astute, even profound, thoughts about the mentally ill, even though psychiatry was not his speciality, and he never worked in a psychiatric hospital. Yet he elaborated an original philosophy of medicine, inspired by vitalism and Naturphilosophie, in his Theory of Fevers, in the $1790 \mathrm{~s}$. He applied these concepts to mental illness in 1803. In particular, his concept of «Gemeingefühl» or coenesthesis could have been useful to Pinel.

When it comes to Pinel's Italian counterpart, Vincenzo Chiarugi (1759-1820), the language question presents a bit of a puzzle. Della pazzia in genere ed in specie. Trattato medico-analitico con una centuria di osservazioni ${ }^{32}$ 
appeared in 1793, thus Pinel had plenty of time to read it. But did he? He referred disparagingly to Chiarugi in the Introduction to the Traité:

\begin{abstract}
Always follow the beaten path, talk of madness in general, in a dogmatic tone, then consider madness in particular and return once again to the ancient scholastic order of causes, diagnosis, prognosis, prescription - that is the task Chiarugi has accomplished. Purposeful research appears in his work only in one hundred observations he published and even among these only few permit conclusive inductions ${ }^{33}$.
\end{abstract}

We cannot prove that Pinel did not read Chiarugi's book. But it would have been quite possible to write the above comments, having read no more than the Table of Contents and scanned the one hundred case histories at the end. Knowledge of French and Latin does not endow one with a full comprehension of Italian, but it certainly suffices to obtain a good idea of a book's contents.

What remains unexplained, except by an extraordinary churlishness on Pinel's part, is his silence regarding the Philosophie de la folie (1791) of the Savoyard physician, Joseph Daquin (1732-1815), despite the fact that the second edition was dedicated to Pinel, in $1804^{34}$.

Perhaps the most convincing explanation for Pinel's selective deafness to books on philosophy and theory is that his ear was tuned to a different "language", that of experience.

"The monographs on alienation published in the second half of this century, either in England or in Germany, have done no more than collect dispersed references, present them in scholastic form, and often produce some brilliant hypothesis",

he writes in the Introduction to the Traité $e^{35}$.

"In contrast, Germany, England, and France have produced men who are ignorant of medical principles, but are guided by healthy judgment, or by some obscure tradition. Devoting themselves to treating the insane, they have brought about many cures, either by waiting, or by subjecting the patient to regular work, or by using gentle means or energetic repression at opportune moments".

Pinel's models were the Reverend Francis Willis (1718-1807), M. D. Oxon., owner of the Gretford asylum in Lincolnshire and physician to king George III, Thomas Fowler (?-1801), M.D.Edinburgh, physician to the Stafford Infirmary in York, the «concierge» of the hospital for the insane at Amsterdam, Father Pouthion of Manosque, John Haslam, M. D. Aberdeen, apothecary at Bethlem Hospital in London, and Jean Baptiste Pussin (1746-1811), "governor of the insane" at the Hospice de Bicêtre in Paris ${ }^{36}$. 
Pinel may well have felt that Latin, now abandoned, should be replaced by the language of experience and experiment, two concepts for which the French have but one single word, «expérience».

\section{Endnotes}

${ }^{1}$ Vienna: Schaumburg, 1801.

${ }^{2}$ Tratado medico-filosofico de la enagenacion del alma o mania (Madrid: Imprenta Real, 1804).

${ }^{3}$ London: Cadell \& Davies, 1806.

${ }^{4}$ Trattato medico-filosofico sopra l'alienazione mentale (Lodi: Orcasi, 1830).

${ }^{5}$ Opera omnia medico-practica et anatomica, novam editionem, Mendis innumeris expurgatam, Notas illustravit et Praefatus est Philippe Pinel, D. M., 2 vols, (Paris: Duplain, 1788).

${ }^{6}$ I, 289-290, and 302-4, n.

${ }^{7}$ Institutions de médecine pratique, traduites sur la quatrième et dernière édition de l'ouvrage anglais de M.Cullen, Professeur de médecine pratique dans l'Université d'Edimbourg, etc., Premier médecin du roi pour l'Ecosse (Paris: Duplain, 1785), 2 vols.

${ }^{8}$ Ibid., ii-iii.

${ }^{9}$ Ibid., ix.

10 Ibid., xiv-xv.

${ }^{11}$ Anon. [J.Gibelin], Abrégé des transactions philosophiques de la Société royale de Londres, (n.p.; n.p., n.d. [Paris: Buisson, 1789]. I, xxxiv-xxv.

${ }_{12}$ P. Pinel, ed., Anatomie et physique animale, vol. 6 in Abrégé des transactions philosophiques de la Société royale de Londres, J. Gibelin, ed., 12 vols. (Paris: Buisson, 1790), 70-76.

13 Ibid., 284-326, read on June 19 and November 3, 1777.

14 Ibid., 292-3.

15 Ibid., 20-21.

Pinel's Notes to volume 6 are found on pages v-vii, $1-5,20-21,52-57,65-76,89-100$, $106-110,135,139,153,160-162,179-188,274-276,327,357,399$, and 446.

16 Ibid., 161-162.

17 Ibid., pp. 187, 55, 57, 69, 109 respectively.

18 Ibid., 399.

${ }^{19}$ Ibid., vii-viii. Pinel's Notes to volume 6 see Note ${ }^{15}$.

${ }^{20}$ P. Pinel, ed., Médecine et chirurgie, vol. 7 in Abrégé des Transactions philosophiques de la Société royale de Londres, J. Gibelin, ed., 12 vols. (Paris: Buisson, 1791), v.

${ }^{21}$ Ibid., vi.

${ }^{22}$ Ibid., vii.

${ }^{23}$ Ibid., 139.

${ }^{24}$ Ibid., 59.

${ }^{25}$ Ibid., 60-67.

${ }^{26}$ Pinel's Notes to volume 7 are to be found on pages $26-67,77-79,85-91,112-150,200-214$, 254-268, 331-334, and 364-377.

${ }^{27}$ E.F.M. Bosquillon and P.Pinel, eds., Matière médicale et pharmacie, vol.9, in Abrégé des Transactions philosophiques de la Société philosophique de Londres, J.Gibelin, ed., 12 vols. (Paris: Buisson, 1791), 275. 
${ }^{28}$ See M. A. Barblanc, Journalisme médical et échanges intellectuels au dix-huitième siècle: Le cas de la Bibliothèque britannique, 1796-1815 in Archives des Sciences, 1977, 30 (3): 287-398.

292 vols., (London: Cadell Jr. \& Davies, 1798).

${ }^{30}$ Faucett, [Robert?], Über Melancholie (Léipsick, 1785) [I have not been able to identify this author].

Auenbrugger, Leopold (1722-1809), Von der stillen Wut oder dem Triebe zum Selbstmorde als einer wirklichen Krankheit, mit Originalbeobachtungen und Anmerkungen (Dessau: Verlagskasse, 1783), $71 \mathrm{pp}$.

Greding, Johann Ernst (1718-1775), Medizinisch-chirurgische Schriften (Altenburg, 1781)

Zimmermann, Johann Georg (1728-1795), Von der Erfahrung in der Arzneikunst (Zürich:

Heidegger, 1763-1764)

Weickard, Melchior Adam (1742-1803), Der Philosophische Arzt (Leipzig, 1775)

31 (Halle: Curt, 1803).

323 vols. (Florence: Carlieri, 1793-1794).

${ }^{33}$ P. Pinel, Traité médico-philosophique sur l'aliénation mentale ou la manie (Paris: Caille \& Ravier, An VIII), xli.

${ }^{34}$ (Chambéry: Gorrin, 1792), 2nd ed., (Chambéry: Cléaz, 1804).

${ }^{35}$ Pinel, Traité, 20-21.

${ }^{36}$ Ibid., xliii-xliv.

\section{Zusammenfassung}

Bevor Pinel durch sein Buch «Traité médico-philosophique sur l'aliénation mentale ou la manie» berühmt wurde, arbeitete er als Übersetzer, vor allem englischer Bücher, wie z. B. von Cullens "Institutes of Practical Medicine", und einer Auswahl aus den «Transactions de la société royale de Londres». Die Autorin verfolgt seine Arbeit als Übersetzer und Mitherausgeber anhand seiner Stellungnahmen in Vorworten und Anmerkungen, und sie untersucht dann, welche Bücher er aus andern Ländern kannte und in seinem Buch, dem «Traité», berücksichtigt hat.

Dora B. Weiner, Ph.D.

Medical Humanities

School of Medicine

UCLA

Los Angeles, CA 90024

U.S.A. 